\title{
Japanese Pacifism Orientation: The Sleeping Asian Tiger or International Peace Keeper?
}

\section{Togu Alexander Nadrian}

Mahasiswa Jurusan Hubungan Internasional, Fakultas IImu Sosial dan IImu Politik, Universitas Katolik Parahyangan

\begin{abstract}
Abstrak
Perang Dunia 2 diakhiri dengan kekalahan Jepang. Artikel 9 yang ditandatangani Jepang pada 3 Mei 1947 menekan Jepang untuk tidak membangun kekuatan militer sebagai bentuk pengukuhan dirinya atas komitmen yang telah Jepang ciptakan guna mempertahankan perdamaian internasional. Untuk tetap mempertahankan keamanan negara Jepang menandatangani Treaty of Mutual Cooperation and Security between the United States and Japan, sehingga Amerika Serikat menjadi pelindung Jepang. Jepang pun mendapat kembali kepercayaan dari dunia internasional dan Jepang menjalin kerja sama internasional di bidang ekonomi dengan berbagai aktor transnasional, sehingga saat ini Jepang dikategorikan sebagain negara dengan salah satu kekuatan ekonomi terbesar di Asia. Namun, seiring berjalannya waktu dunia internasional dewasa ini mengalami krisis keamanan dari berbagai aktor transnasional seperti terorisme internasional, pengembangan teknologi nuklir Korea Utara, dan ancaman lainnya. Dengan berbagai ancaman yang muncul, juga partner terbaik Jepang, Amerika Serikat kini berada dibawah kepemimpinan Donald Trump yang kebijakannya berorientasi America First, perlukah Jepang kembali menajamkan tajinya, atau tetap pada orientasi pasifismenya?

Keywords: Japan, military, pacifism, national security, role, international system, rational actor, Asia, non-traditional security
\end{abstract}

\section{Introduction}

Japan known as one of the strongest country in the world, especially by its economic power. By Japan's lost in the World War II, Japan shifted their orientation from imperialism to pursue economic power.

In the first year of Allied Occupation (1945-1951), through complex process, eventually Japan emerged as US major ally. In the 1952, they sealed Treaty of Mutual Cooperation and Security between United States and Japan. Since the establishment of its cooperation treaty, Japan shifted their national interest. Japan allowed US military presence to enter their territory. In 1957, US-Japan established U.S. Forces Japan (USFJ) with U.S. army, U.S. marine corps, U.S. navy, and U.S. Air Force

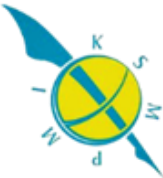


elements. Since the 1952 defense treaty created until today, Japan merely ever involved in any military activity by their aid in purpose to support US in Afghan war, beside their involvement in any UN peacekeeping operation. In 2012, Shinzo Abe selected as Prime Minister of Japan for the second time. He created more interpretion of article 9 where he stressed on building military capacity as self defense.

Japanese pacifism orientation has framed Japan's movement in uncertain international system. Trump with his American first orientation and his conservative power ideology had triggered Asia region's threat, North Korea, t0 repare more of its power. After US showed off their power by launched their missile to Syria and Afghanistan, President Trump and Vice President Pence stated that US has run out of patience for North Korea. Regarding the US threats, North Korea set themselves on maximum alert. China also now has emerged as one of the most powerful country in the world and became rival for United States. Considering escalated tension between US, North Korea, and China that happened in East Asia, Japan as the powerful country also has influence. But Japanese Pacifism Orientation has limited their military influence. Regardless, Japan has become one the most successful country by their economic orientation since 1952.

By using Neo-Realism that forcing a state should be survived in the anarchy of international system and Game theory that stated state as rational actor, the writer would like to compare the strength and weakness of Japanese Pacifism Orientation that being Japanese framework for their foreign policy.

\section{The Sleeping Asian Tiger?}

Article 9 may has limited Japanese military to develop its capacity. In 2014, Shinzo Abe had interpreted article 9 for a broader means as the right for Japan develop its military capability in purpose for collective self defense. ${ }^{1}$ Furthermore, Shinzo

\footnotetext{
${ }^{1}$ The Japan Times, "Abe Guts Article 9" http://www.japantimes.co.jp/opinion/2014/07/02/editorials/abe-guts-article9/\#.WPWkKoiGPIU accessed April 17, 2017
} 
Abe has increased Japanese state budget for military. It is recorded that Japan allocated their state budget for military to 5.13 trillion Yen ( $\$ 43.66$ billion) by 1 April 2017..$^{2}$ Japan also developed their ballistic missile defense in response of North Korea's Aggression. ${ }^{3}$ Beside in response of North Korea's aggression, Japan also sold military ships and equipment to Philippines and Vietnam in order to deter China's aggression in South China Sea. ${ }^{4}$ In order to maintain Japan's defensein their own region, Japan has done the right thing. North Korea and China have increased their deterrence and influence to showed off their power in region. Japan known as one of the most successful state in economic, but does their military has influence in order to deter North Korea and China? Stated that Abe had increased Japan's budget allocation for military. Ironically, article 9 limited Japan's defense budget approximately to $1 \%$ of GDP. ${ }^{5}$ Even in the United Nations, Japan has less military influence regarding their military power and the $1 \%$ budget allocation. It is contrast with Japan's best ally, United States considered as the most powerful military capacity in the world. ${ }^{6}$

With this situation in the region, Japan should have more chance to create maneuver. Japan should not be bridled in their own region. Japan has developed their economic power since their lost in World War II and has been recognized as the most successful country for economic power for a long time. Emerging state such China and power oriented state such North Korea should be deterred by the presence of

\footnotetext{
2 Reuters, "Japan's government approves record military spending" http://www.reuters.com/article/us-japan-defence-budget-idUSKBN14B01C accessed April 17,2017

3 ibid

${ }^{4}$ Council on Foreign Relation, "Territorial Disputes in the South China Sea" http://www.cfr.org/global/global-conflict-tracker/p32137\#!/conflict/territorial-disputes-inthe-south-china-sea accessed April 17, 2017

${ }^{5}$ Cumberland Advisors, "Defense Budget and Market \& Japan" http://www.cumber.com/defense-budgets-and-markets-japan/ accessed April 17, 2017 ${ }^{6}$ Military1, "How Much Stronger is the US Military Compared with The Next Strongest Power?" https://www.military1.com/army/article/402211-how-much-stronger-is-the-usmilitary-compared-with-the-next-strongest-power/ accessed April 17, 2017
} 
Japan. Unfortunately, their own pacifism orientation has limited their role in response to North Korea's aggression and escalated China's presence in South China Sea.

North Korea has been developing their missiles capability and also has tested their missiles for times. Their missiles capability has grown to the extend that become a threat for United States. Trump's administration declared their courage to deter North Korea as diplomatic ways has not been very effective to reduce North Korea's intention. Geopolitically, Japan located as neighbor for North Korea. No doubt that missiles threat from North Korea becomes deter for Japan.

China also becomes a threat for Asia. Japan may have no disputed island in South China Sea. But Senkaku Island is a disputed island that claimed by China and Taiwan. Move on from Senkaku dispute, China has been a hegemony in South China Sea. Brunei, Malaysia, Vietnam, Cambodia, and Philippine claimed their territory in South China Sea. These countries have no power to compete China. If these countries tried to deter China, it will be disaster for these countries since they have dependence with China, especially in trade cooperation. If Japan let themselves to increase their military power to deter North Korea and China, Japan could influence the South East Asian Nations. Investment become means for approach South East Asian. The more power Japan have, the more influence they have. Japan's power could compete China's aggression to attract South East Asian. ${ }^{7}$ Japan also has no certain dispute with South East Asian. Therefore, by the power and technology Japan have could shift South East Asian preferences to Japan. Thus, building its military capacity will lead Japan as the leader of its international system of Asia. Japanese power will influence South East Asian Nations and together deter North Korea and China. Japan also will have more existence and influence in United Nations in military purposes. Therefore, by letting Japan develop their military power, it will give the chance for Japan to wake up and stand up once more as Asian Tiger.

${ }^{7}$ The National Interest, "China and Japan's Battle for Influence in South East Asia" http://nationalinterest.org/feature/china-japans-battle-influence-southeast-asia-14006 accessed April 30, 2017

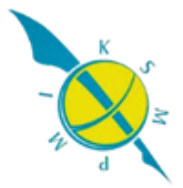




\section{The International Peace Keeper?}

If we considered the military power as means for pursue leading role in international system, they may fulfill the Neo-Realism theory to survive in international system. However, In this modern century, military power is not the only national interest that state should pursue. As what stated on UNDP 1994 on Human Security that non security issues matter in this modern century, ${ }^{8}$ Japan considered as a rational actor. An actor could be considered as a rational if it decides to pursue its national security. The concept of national security could be non traditional agenda based on what is at stake.

Japan had turned their national interest from "imperialism" to "economic development" since their lost in World War II. Framed by their own Pacifism orientation, Japan could focus on what really matters in Japan. Misunderstanding of Japanese security policy becomes a failure since Japan try to protect their national interest through non security agenda.

Japan's desire to expand export and investment market for Japanese firms can be viewed as a form of "comprehensive security" (Long 1999). Comprehensive security not merely just looked after traditional security, but also how does a state arrange in order to achieve their national stability. Beside Japan's intention to achieve their own national security, Japan also played important role in international system. Japan has been actively playing their role in East Asia in non traditional security issues. Japan was one of the state that play a main role in order to establish Asia-Pacific Economic Cooperation (APEC), Asia Development Bank (ADB), East Asia Summit (EAS), and ASEAN+3(ASEAN plus China, South Korea, and Japan). ${ }^{9}$

\footnotetext{
${ }^{8}$ United Nations Development Programme, "Human Development Report 1994" (New York: Oxford University Press, 1994) http://hdr.undp.org/sites/default/files/reports/255/hdr_1994_en_complete_nostats.pdf accessed April 18, 2017.

${ }^{9}$ Howe, Brendan M. and Joel R. Campbell. 2013. "Continuity and Change: Evolution, Not Revolution, in Japan's Foreign and Security Policy Under the DPJ." Asian Perspective 37 (1): 99-123. https://search.proquest.com/docview/1365738748?accountid=31495. Accessed April $18^{\text {th }} 2017$
} 
Japan actively leading Asian integration. Hashimoto Doctrine in 1997 called for broader mutual cooperation and proactive to solve regional problems. One of the Japan's great effort in solving regional problem is the creation of Asian Monetary Fund (AMF). Regarding the Asian financial Crisis (1997-1998) that has been a disaster for Asian countries economic, Japan proposed the creation of AMF as a stimulants for Asian funding and proliferation of IMF. Unfortunately US forestalled the AMF. Therefore, Japan eagerly to embrace another institution in order to embrace Asian countries. ${ }^{10}$ Japan has continued with such overtures under successive administrations. Furthermore, Japan bears 20 percent of the total UN budget, has extended hundreds of billions of dollars in overseas development assistance (ODA) to 185 countries and regions, and has contributed extensively to peacekeeping, peacebuilding, humanitarian, and reconstruction missions. ${ }^{11}$

Japan has done their effort to fulfilled their national interest. Letting themselves framed by the Pacifism Orientation has turned their national interest and turned Japan into a more rational actor. Japan also being active in Asian integration. Japan's proactive and reactive effort in region could not be forgotten. Using the Neo-Realism Theory, Japan has been a great influence for its region. Their intention to pursue non security agenda more than justified Japan as a rational actor, but also became a stair for Japan to be a great influence in Asia. Therefore by their shifted interest and proactive attitude to its region, Japan should meet the essence of their Pacifism Orientation. Japan not actively involved in military power to pursue peace, but Japan create peace and develop its region.

\section{Conclusion: The Sleeping Asian Tiger or International Peace Keeper?}

External issues may have deter Japan's presence in the region. It has been a threat for Japan and may be Japan should let them to put away the pacifism orientation. Japan may develop their military capability. But it can be a boomerang for Japan.

\footnotetext{
${ }^{10}$ ibid

11 ibid
} 
Japan may deter its region because the capability of Japan to develop their military power regarding their economic power. Japan could lose trust from another Asian partner because Japan has been known as a good partner since Japan never showed uncertain intention. It could harm their presence and jeopardized them to survive in international system as a great influence.

Regardless of Asian countries perspective on Japan, external issue has been a serious threat. North Korea's and China's aggressiveness in Asia has been a serious threat for Japan. If Japan does not let themselves to move out from Pacifism Orientation, Japan may be trapped in this uncertain situation for unceration periode. It could also jeopardized their recognition as a rational actor. State as a rational actor has to choose the best option towards their security and not let themselves trapped in uncertain situation.

By this brief writing about Japanese Pacifism Orientation, writer would like urge Japan position regarding external issues and uncertain intention from North Korea, China, even United States. In writer's opinion, the next step that Japan should do is to emphasize their position by develop their military power. Another Asian countries especially South East Asian may more pay attention and observe Japan's intention also could harm their relation with Japan. But state as rational actor should not let themselves trapped in uncertain situation and state has to choose the most rational option to gain their existence in international system. Therefore, the writer thought that Japan should develop their military capacity and once again stand up as Asian Tiger.

\section{References:}

Michael K. Connors, Remy Davison, and Jorn Dosch, "The New Global Politics of the Asia Pacific." (New York: Routledge,2004), 60-70.

Robert Jackson, Georg Sorensen, "Introduction to International Relations Theories and Approaches" (United Kingdom: Oxford University Press, 2013), 48-50

Paul Williams,"Security Studies: An Introduction" (London: Routledge, 2008)

Howe, Brendan M. and Joel R. Campbell. "Continuity and Change: Evolution, Not Revolution, in Japan's Foreign and Security Policy Under the DPJ." Asian Perspective 37, no. 1 (Jan, 2013): 99-123. https://search.proquest.com/docview/1365738748?accountid=31495.

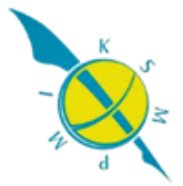


Ministry of Foreign Affairs of Japan. "Japan's Security Policy" last modified April 27, 2016 http://www.mofa.go.jp/policy/security/index.html 